\title{
ZAPOZNANE KWESTIE W TEORII PEDAGOGII OSOBY: CIELESNOŚĆ, PRZYGODNOŚĆ, PRZEBACZENIE
}

Streszczenie: W tekście podjęto próbę odpowiedzi na pytania: czy teoria osoby oraz teoria pedagogii osoby są adekwatne do ludzkiej kondycji i czy są teoriami wspierającymi pedagogię osoby, czy może ową pedagogię utrudniają, zachęcając do urzeczywistnienia nieosiągalnego dla człowieka modelu osoby? Odpowiadając na nie, rozważam problem przebaczenia jako jednego z elementów aktualizacji osobowego wymiaru człowieka oraz problem wad moralnych, które rozwijają się w ludzkiej naturze obok cnót moralnych. Z przeprowadzonej analizy wyprowadzam wniosek, że osiągnięcie osobowej pełni jest dla człowieka niemożliwe. W konsekwencji pytam, o jakie wymiary powinna zostać poszerzona pedagogia osoby, aby była adekwatna do ludzkiej kondycji. Identyfikuję dwie kwestie, które zostały zapoznane w teorii pedagogii osoby: wychowanie do akceptacji własnej cielesności i związanej z nią przygodności oraz wychowanie do przebaczenia sobie i innym. Swoje rozważania wspieram ponadto refleksją teologiczną.

Słowa kluczowe: osoba, pedagogia, cielesność, przygodność, przebaczenie

Gdy Jacques Maritain wskazuje na przyczyny upadku średniowiecznej kultury sakralnej i kształtowania się nowego, czysto ludzkiego typu kultury, czyli epoki nowożytnego humanizmu, stwierdza: „Gdy poryw heroizmu, który tak ponosił stworzenie, zatrzymał się i gdy opadło ono do własnego poziomu, poczuło się zmiażdżone ciężką budową świata, którą samo wzniosło, i odczuło strach przed swoją nicością. Stworzenie chce być "wzgardzone», to znaczy uważane za nic przed Bogiem - przez świętych; wie, że oddają mu oni sprawiedliwość. Nie chce być wzgardzone przez ludzi cielesnych, czy to będą teologowie, czy filozofowie, duchowni czy mężowie stanu. A jednak poczuło się tak właśnie wzgardzonym u schyłku średniowiecza” (Maritain 1981, s. 10). Przytoczone słowa skłaniają do refleksji nad kondycją człowieka oraz nad treścią kulturowej narracji o człowieku. Owa narracja - jak się okazuje - może nie być adekwatna do ludzkiej kondycji, może „miażdżyć” człowieka, który próbuje oceniać siebie i innych w jej świetle, a w skrajnych przypadkach może prowadzić go do pogardy dla siebie i innych. Słowa 
Maritaina traktuję jako punkt wyjścia do refleksji nad teorią osoby i będącą jej implikacją teorią pedagogii osoby, ponieważ - jako teorie - są one częścią kultury. Towarzyszy mi przy tym pytanie: czy teoria osoby oraz teoria pedagogii osoby są adekwatne do ludzkiej kondycji? I wynikające $\mathrm{z}$ niego, a przy tym dla pedagoga ważniejsze: czy są teoriami wspierającymi pedagogię osoby, czy może ową pedagogię utrudniają, zachęcając do urzeczywistnienia modelu osoby, którego nie da się urzeczywistnić? Dlaczego jest to niemożliwe? Ponieważ - jak mówi Hannah Arendt - jest to model „nadludzki”: „próby zdefiniowania natury człowieka z łatwością prowadzą do idei, która wyraźnie jawi nam się jako «nadludzka»" (Arendt 2010, s. 29). Jeśli odpowiedź na niniejsze pytania wskazałaby na rozbieżność między teoriami osoby i jej pedagogii a ludzką kondycją, to należałoby również postawić kolejne: jakie kwestie w teoriach osoby i pedagogii osoby zostały zapoznane?

Odpowiedzi poszukiwał będę w ramach filozofii wychowania jako jednego z fundamentów myśli pedagogicznej. Dane wyjściowe do refleksji filozoficznej czerpał będę z doświadczenia. Próbując z kolei rozwiązać zasygnalizowany problem, sięgnę do teologii, stając tym samym na stanowisku wypracowanym przez Jacques’a Maritaina, według którego filozofia może korzystać z danych teologicznych, pozostając filozofią, jeżeli zachowuje własną perspektywę metodologiczną, to znaczy punktem wyjścia do refleksji jest kondycja człowieka, a nie prawdy objawione (Horowski 2013).

Spróbuję odpowiedzieć na postawione powyżej pytania, rozpoczynając od refleksji nad teorią osoby. Ze względu na wielość teorii dążących do ujęcia ludzkiego - osobowego - bytu, na początku rozważań konieczne jest doprecyzowanie, że punktem odniesienia dla dalszych analiz będzie neotomistyczna teoria osoby, rozwijana między innymi przez Jacques’a Maritaina oraz Karola Wojtyłę, która $\mathrm{w}$ aspekcie dynamicznym, rozwojowym bardzo dobrze koresponduje $\mathrm{z}$ wypracowaną przez Jacka Woronieckiego teorią cnót moralnych. Czy zatem neotomistyczna teoria osoby jest adekwatna do kondycji człowieka, czyli czy człowiek może stać się w pełni osobą (według neotomistycznego modelu osoby)?

\section{Czy człowiek może stać się w pełni osobą?}

Teoria osoby wskazuje niewątpliwie na wyjątkowość człowieka. Jakie jest źródło owej wyjątkowości? Teoria ta podkreśla, że tylko człowiek - w przeciwieństwie do innych żyjących bytów: roślin i zwierząt - jest istotą duchową i jako taki jest wolny (nie podlega determinizmom, którym podlegają rośliny i zwierzęta). Jego duchowość ujawnia się w jego działaniu. Człowiek jest podmiotem - jego działanie wynika z wnętrza; poszczególne czyny znajdują swoje źródło w jego wolnych decyzjach. Jak pisze Maritain: „Człowiek jest osobą, która trzyma we władzy samą siebie poprzez swój umysł i poprzez swoją wolę. Nie istnieje po prostu jako byt fizyczny. Posiada w sobie istnienie bogatsze i szlachetniejsze, duchowe istnienie właściwe poznaniu i miłości” (Maritain 1988, s. 95; Maritain 1981; Maritain 1993; 
Maritain 2005). W swojej duchowości człowiek upodabnia się ponadto do Absolutu, w religii nazywanego Bogiem, który identyfikowany jest jako byt duchowy - wolny od materialnych uwarunkowań.

Mimo duchowej natury upodabniającej człowieka do Absolutu osoba ludzka znacząco różni się od bytu absolutnego. Owe różnice związane są przede wszystkim z cielesnością. Człowiek do swojego działania potrzebuje ciała. Bez niego nie jest w stanie ani poznawać, ani wprowadzać w życie własnych decyzji. Duchowość człowieka posiada więc swoją specyfikę. W tomistycznej teorii osoby owa specyfika znalazła wyraz w teorii hylemorfizmu - duch stanowi formę dla materii ciała, które duch sobie organizuje. Ciało uwarunkowuje aktywność ludzkiego ducha, umożliwia ją. Równocześnie jednak z owym ciałem wiążą się liczne ograniczenia: fizyczne, ekonomiczne, społeczne (Maritain 1993). Człowiek nie jest zatem doskonałym duchem.

Do przytoczonych powyżej bardzo skrótowo twierdzeń trzeba dopisać jeszcze jedno, wynikające ze spojrzenia na osobę w perspektywie rozwojowej. Według niego osoba w pewnym sensie rozwija się w człowieku, jest owocem trwającej całe życie pracy człowieka nad sobą. W niniejszym twierdzeniu ujawnia się ubóstwo języka, którym się posługujemy. Brakuje nam słów, aby sugestywnie odróżnić bycie osobą od stawania się nią. W teorii osoby człowiek $\mathrm{z}$ jednej strony jest bowiem osobą od poczęcia, czyli od momentu zaktualizowania pierwszego aktu go konstytuującego jego istnienia, a z drugiej strony - staje się osobą, gdy w swoim rozwoju dochodzi do momentu uporządkowania aktywności własnej ciała w taki sposób, aby była ona zintegrowana $\mathrm{z}$ decyzjami podejmowanymi przez władze duchowe: rozum i wolę. O owym rozwoju Maritain mówi w następujących słowach (termin „osobowość", którego uży to w tłumaczeniu, nie najlepiej oddaje sens opisywanej rzeczywistości): „Mogę się rozwijać w kierunku osobowości, inaczej mówiąc w kierunku opanowania i niezależności, właściwych duchowi, mocą którego istnieję. Albo też mogę rozwijać się w kierunku jednostkowości, inaczej mówiąc, w kierunku poddania się skłonnościom, które są we mnie obecne z racji materii i dziedziczności” (Maritain 1981, s. 31). Osiągnięcie jedności między rozumem a cielesnością związane jest przy tym z rozwojem cnót moralnych, a zwłaszcza cnót kardynalnych: roztropności, sprawiedliwości, umiarkowania i męstwa, które wtórnie decydują o moralnej jakości działań, ale pierwotnie wskazują na wolność i podmiotowość człowieka w jego działaniu - na fakt, że owo działanie znajduje źródło w rozumnej decyzji, a nie w aktywności własnej ciała, czyli w psycho-emotywnych uczynnieniach (Horowski 2009).

W teorii osoby stwierdza się również, że osoba - jako byt świadomy - dąży do ujawnienia w czynach osobowego charakteru swojego bytu (Wojtyła 1994). Owe dążenia nie zawsze zakończone są jednak sukcesem. Uwarunkowania związane z cielesnością, a zwłaszcza pożądaniem cielesnym czy różnego rodzaju lękami, sprawiają, że w poszczególnych czynach osobowy charakter podmiotu może nie zostać ujawniony. W teorii osoby wskazano nawet na konsekwencje takiego działania, 
w którym więcej motywacji bierze się z pożądań zmysłowych lub innych emocji niż z osądu rozumu identyfikującego prawdę i dobro. Jak piszą Jacek Woroniecki czy Karol Wojtyła, ową konsekwencją jest wstyd (Wojtyła 1986; Woroniecki 200o). Trafnie opisuje tę prawidłowość Karol Górski: „wstyd płynie z faktu, że człowiek nie umie opanować odruchów instynktu. Jest to niezmiernie dla intelektu upokarzające, iż on, widząc rzeczy tak, jak one są, nie ma pełnej władzy nawet nad własnem ciałem, które czasem wyłamuje się spod jego kontroli" (Górski 1936, s. 35).

Po tym krótkim w prowadzeniu w teorię osoby wróćmy do postawionego w tytule tej części artykułu pytania o możliwość aktualizacji osobowego bytu człowieka. Stawiam tezę, że owa aktualizacja jest trudna do osiągnięcia, a nawet w pewnym sensie niemożliwa. Weryfikując ją, odwołam się do kilku przykładów pokazujących, że osiągnięcie pełni osobowego rozwoju, którego model został przedstawiony powyżej, jest praktycznie niewykonalne.

Pierwszym z nich jest ułożenie relacji między dwiema osobami, z których jedna skrzywdziła drugą. Niekiedy, ze względu na okoliczności życiowe, jest to konieczne. Wobec takiego wyzwania staje na przykład kobieta, żona i matka, która została zdradzona przez swojego męża. Zdaje ona sobie sprawę, że dla dobra dzieci i ich rozwoju powinna spróbować ułożyć na nowo stosunki z mężem (niezależnie od prawnej sytuacji ich małżeństwa), tak aby mógł on pełnić funkcje rodzicielskie wobec dzieci. Mimo że doskonale rozumie potrzebę uporządkowania relacji z mężem, nie jest w stanie tego uczynić. Targają nią bowiem zbyt duże emocje, co oczywiście negatywnie przekłada się na rozwój dzieci. Obserwując własne działania oraz ich wpływ na bliskie jej osoby, zauważa ona równocześnie, że w jej działaniu więcej jest emocji niż roztropności, że nie panuje nad emocjami. Odwołując się do modelu osobowego rozwoju wypracowanego w ramach neotomizmu, należałoby stwierdzić, że w swoim działaniu nie jest ona w pełni osobą.

O tym, jak trudno uporać się z emocjami związanymi z doznaną krzywdą, pisze Anselm Grün w książce pt. Przebacz samemu sobie...: „Jedni noszą w sobie ślady surowego wychowania: mówiono im, że powinni każdemu przebaczyć, a tymczasem oni czują, że nie mogą się na to zdobyć - że dawno zadana rana ciągle jeszcze sprawia ból. Niektórzy nakaz przebaczania pojmują w tym sensie, że powinni stłumić w sobie uczucie złości i gniewu przeciwko tym, którzy ich skrzywdzili, i że nie pozostaje im nic innego, jak tylko ludziom tym jak najszybciej przebaczyć. To wszakże przekracza ich siły, stale jeszcze bowiem odczuwają gniew i urazę. Czują, że te uczucia ich paraliżują" (Grün 2001, s. 7). Traktując poważnie spostrzeżenia niemieckiego psychoterapeuty, powinniśmy stwierdzić, że niemożliwe jest w pełni osobowe funkcjonowanie w następstwie doznanej krzywdy i że ci, którzy nie potrafią przebaczyć, ponieważ „zadana rana ciągle jeszcze sprawia ból”, nie osiągnęli poziomu osobowego rozwoju.

Ułożenie relacji z kimś, kto skrzywdził, zawiódł, czy nawet przebaczenie owej osobie wiąże się z niezwykle trudną decyzją, w której wyraża się bardzo wysoki poziom osobowego rozwoju człowieka. Biorąc to pod uwagę, skłonni jesteśmy 
usprawiedliwić trudności związane z jej podjęciem. Życie codzienne przynosi jednak liczne sytuacje, w których człowiek mierzy się ze słabościami własnymi oraz innych ludzi, wobec których nie jest już tak pobłażliwy. Mimo że nie chce się na nie zgodzić, to niejednokrotnie przekonuje się o ludzkiej wobec nich bezsilności. Grün z perspektywy doświadczeń terapeutycznych mówi o konieczności pojednania się z samym sobą, popatrzenia życzliwie „na to, co mi zupełnie nie odpowiada, co jest tak całkowicie sprzeczne $\mathrm{z}$ moim wyobrażeniem o tym, jakim chciałbym być - na moją niecierpliwość, na mój lęk, na moje poczucie własnej wartości. [...] Nawet bowiem kiedy sądzimy, że już od dawna pogodziliśmy się z samym sobą, pojawiają się w nas ciągle słabości, które nas gniewają, których najchętniej byśmy się wyparli” (Grün 2001, s. 36-37). I kontynuuje: „Musimy się pogodzić z tym, że jest w nas nie tylko miłość, ale także nienawiść, że pomimo wszystkich religijnych i moralnych wysiłków są w nas także skłonności mordercze, rysy sadystyczne i masochistyczne, agresje, złość, zawiść, nastroje depresyjne, lęk i tchórzostwo. Jest w nas nie tylko tęsknota duchowa, ale też obszary bezbożne, które bynajmniej nie chcą być inne" (Grün 2001, s. 37-38).

Nie wchodząc w te wszystkie zagadnienia, które wymienia Grün jako specjalista w dziedzinie terapii, zwróćmy uwagę na coś, co doświadczane jest przez każdego człowieka - na różnego rodzaju wady: pychę, próżność, zazdrość, lenistwo, gniew, chciwość, łakomstwo, nieczystość (Mróz 2010). Kształtują się one na drodze podobnej do tej, na której rozwijają się cnoty moralne. Wady, podobnie jak cnoty, są sprawnościami, które swój początek znajdują w drobnych czynach i z czasem zaczynają odnosić się do coraz poważniejszej materii (Woroniecki 1938). Ich źródeł poszukiwać należy bardzo często w młodości, gdy rozwój osoby jest dopiero na początkowym etapie, gdy o czynach decydują emocje, pożądania, lęki. W życiu dorosłym przybierają one postać ukształtowanych i utrwalonych wad moralnych.

Przyglądając się życiu konkretnych osób, nietrudno zauważyć, że każda zmaga się z mniejszymi lub większymi wadami oraz że nosi w sobie rany, które trudno uleczyć, a przy okazji doświadcza własnej bezsilności, jeżeli chodzi o wybaczenie ludziom, za sprawą których one powstały. Jeżeli zatem w życiu każdego człowieka istnieją takie obszary, w których nie do końca panuje on nad swoimi emocjami, a to one mają znaczący wpływ na jego czyny, to znaczy, że nie istnieją ludzie, którzy osiągnęli w pełni poziom osobowego rozwoju. Wniosek wydaje się paradoksalny: nikt nie jest w stanie stać się w pełni osobą.

\section{Ku kwestiom zapoznanym w teorii pedagogii osoby}

Teoria osoby na gruncie antropologii jest teorią opisową - ujmuje byt ludzki w jego istocie oraz dynamizmie rozwojowym, w tym ostatnim aspekcie kreśląc prawidłowości związane z rozwojem człowieka jako osoby. Kiedy przeniesiemy jej tezy na poziom pedagogiki, staje się jednak teorią normatywną, gdyż wyznacza najpierw teleologię wychowania. Jej implikacją jest uznanie wychowania za działanie 
prowadzące do ujawnienia się osoby; do - jak mówi Marian Nowak - „«majeutyki osoby», czyli wzbudzenia osoby w wychowanku" (Nowak 2005, s. 243). W praktyce oznacza to uznanie, że celem wychowania jest osiągnięcie przez wychowanka jedności w działaniu na fundamencie cielesno-duchowej złożoności, tak aby było ono konsekwencją rozumnych decyzji, a nie chwilowych emocji czy lęku. Jest to cel, który niewątpliwie trudno kwestionować. Został bowiem sformułowany w wyniku głębokiej refleksji nad człowiekiem. Równocześnie jednak jawi się jako niezwykle trudny, a wręcz niemożliwy do pełnej realizacji. Jakie skutki może przynieść stawianie przed wychowankiem celu, którego nie da się osiągnąć? Czy posługiwanie się teorią osoby jako teorią normatywną w ramach kulturowej narracji nie przynosi, obok z pewnością wartościowych wskazówek co do kierunku ludzkiego rozwoju, także takich konsekwencji, które rzutują negatywnie na ów rozwój?

Gdy osobowy charakter ludzkiego bytu wpisujemy w teorię pedagogiczną, uznając go za cel zabiegów wychowawczych, wówczas traktowany jest on jako norma, do której realizacji dąży się w wychowaniu. Norma ta wykorzystana zostaje także do wartościowania, czyli na jej podstawie stwierdza się, czy dany człowiek jest osobą, czy jeszcze nią nie jest, to znaczy czy działa rozumnie, czy miotają nim ciągle różnego rodzaju emocje i namiętności. W zależności od wieku danego człowieka ów drugi poziom osobowego rozwoju może zostać uznany za dopuszczalny lub świadczący o nieprawidłowym rozwoju. Motywowanie działań emocjami wydaje się charakterystyczne i zrozumiałe w przypadku młodego człowieka ze względu na prawidłowości związane z jego rozwojem, natomiast w przypadku dorosłego skłonni jesteśmy oceniać je negatywnie. I tak robimy. Za pomocą tego kryterium oceniamy siebie i innych. Jeżeli jesteśmy uczciwi w tej ocenie, wypada ona negatywnie. To z kolei może prowadzić do rozczarowania sobą i innymi, a w przypadku własnej osoby także do stwierdzenia, że cel, jakim jest osobowy rozwój, jest dla mnie osobiście nieosiągalny, i w konsekwencji skutkować rezygnacją z dążenia do niego. Zjawisko odwrócenia się od wartości, ku której się dąży, na skutek niemożności jej osiągnięcia opisuje Max Scheler w teorii resentymentu (Scheler 1997). Schemat naszkicowany przez niemieckiego filozofa z pewnością dałoby się zastosować do wielu ludzi, którzy w dążeniu do w pełni osobowego działania doświadczają porażek i przekonują się o własnej bezsilności, jeżeli chodzi o realizację tego celu. Dochodzą wówczas do wniosku, że ich przerósł, i przyzwalają na dominację w ich działaniu cielesnych pożądań i emocji.

Jeżeli jednak celu, jakim jest w pełni osobowe działanie, nie da się urzeczywistnić, to za opisane powyżej rozczarowania odpowiedzialność ponosi kulturowa narracja o osobie oraz o pedagogii osoby. Zamazano w niej bowiem prawdę o specyficznej kondycji osoby ludzkiej - specyficznej, ponieważ nie tylko duchowej, ale i cielesnej. Konsekwentnie należałoby postawić pytanie, jakie kwestie zostały zapoznane szczególnie w teorii pedagogii osoby ludzkiej. Trudno w tym miejscu dokonać pełnej diagnozy - zresztą jest ona niemożliwa i z czasem z pewnością pojawią się kolejne wskazówki, jak odpowiedzieć na powyższe pytanie - zwróćmy 
jednak uwagę na dwa zagadnienia, które czynią teorię pedagogii osoby bardziej adekwatną do ludzkiej kondycji. Są one ze sobą powiązane i odnoszą się do trzech wspomnianych w tytule kategorii: cielesności, przygodności oraz przebaczenia. Owe zagadnienia to wychowanie do akceptacji własnej przygodności, która związana jest przede wszystkim z cielesnością, oraz wychowanie do przebaczenia sobie i innym. Przyjrzyjmy się, jak przekładają się one na teleologię wychowania.

Na czym miałoby polegać wychowanie do zaakceptowania własnej cielesności i związanej z nią przygodności? Z pewnością nie chodzi o zgodę na własną bylejakość. Bardziej o to, aby uznać, że jako istoty nie tylko duchowe, ale także cielesne, posiadamy ograniczenia. Są to najpierw ograniczenia poznawcze. Poznajemy bowiem intelektualnie, ale dane do takiego poznania docierają do intelektu za pośrednictwem zmysłów. Są one niepełne, często obarczone błędem. Możemy więc mylić się, podejmować błędne decyzje, krzywdząc w konsekwencji siebie i innych. W akceptacji własnej cielesności chodzi również o to, by uznać, że jako istoty cielesno-duchowe w każdym działaniu doświadczamy poruszeń władz cielesnych - lęków lub namiętności, w zależności od przedmiotu odniesień. Niekiedy są one na tyle silne, że nie jesteśmy w stanie im sprostać. Tego samego dnia możemy doświadczyć zarówno własnej osobowej wielkości, gdy podejmujemy czyn wskazany przez rozum jako dobry pomimo wiążących się z nim trudności, jak i własnej słabości, gdy rezygnujemy z dobra pod wpływem lęku o utratę czegoś dla nas cennego. Świadomość ograniczeń związanych z cielesnością i przygodnością własnego bytu pozwala podtrzymać dążenie do działania jak najbardziej osobowego mimo porażek, jakich doświadcza się nieustannie na jego drodze, a które są nieuniknione, gdyż życie stawia przed człowiekiem coraz poważniejsze problemy do rozwiązania.

Akceptacja cielesności i tym samym przygodności ludzkiego bytu jest także elementem wychowania do przebaczenia. Nie sposób dążyć do osobowego spełnienia, nie stając oko w oko ze słabościami swoimi oraz innych ludzi. Owe słabości przekładają się na czyny, których konsekwencją jest zło: zarówno doświadczane, jak i powodowane. Rozwój osobowy domaga się zatem przebaczenia - najpierw sobie tych czynów, do których nie powinno dojść, a których podmiot - ze względu na własną słabość - jest sprawcą; czynów, które rodziły się pod wpływem pychy, zazdrości, chciwości, lenistwa, gniewu, łakomstwa, nieuporządkowanej pożądliwości zmysłowej; które krzywdziły zarówno sam działający podmiot, jak i jego bliskich, i dosięgały także osób obcych. Są to czyny, z którymi łączy się wstyd i o których raczej się nie wspomina. Następnie rozwój osobowy domaga się przebaczenia także innym, szczególnie bliskim oraz tym, którym powierzono dobro rozwijającego się człowieka. Są to osoby, które powinny rozumnie zadbać o owo dobro, a ze względu na swoją przygodność nie w każdej sytuacji sprostały temu zadaniu. Dopuściły do zła albo w konsekwencji niewiedzy czy niezbyt starannego rozeznania sytuacji, albo pod wpływem własnych wad moralnych. Doświadczenie słabości własnej oraz innego człowieka może prowadzić do pogardy dla tego, kto 
charakteryzuje się ową słabością. Przebaczenie, rozumiane zazwyczaj jako przezwyciężenie urazy żywionej wobec innego człowieka, posiada także inny wymiar. Obejmuje ono przezwyciężenie pogardy żywionej wobec tych, którzy zawiedli, nie sprostali zadaniu, okazali się osobowo niedojrzali (Bell 20o8; Richards 1988).

Przeprowadzone powyżej bardzo skrótowo analizy skłaniają do wniosku, że wychowanie do akceptacji własnej przygodności i cielesności oraz wychowanie do przebaczenia sobie i innym stanowią istotny element pedagogii osoby, ponieważ pedagogia ta odnosi się do specyficznej osoby, której natura jest cielesno-duchowa, a nie czysto duchowa. Włączenie do procesu wychowania wspomnianych powyżej celów sprawia, że staje się ono adekwatne do rzeczywistej kondycji człowieka. Jeżeli owe cele uda się zrealizować, podmiot wychowania może zmierzać do aktualizacji swojego osobowego charakteru, mimo że na tej drodze doświadczy porażek i będzie przez innych raniony.

\section{Dopowiedzenie teologiczne}

Z przeprowadzonych filozoficzno-pedagogicznych refleksji wynika, że pełnia osobowego rozwoju jest dla człowieka nieosiągalna, a wpisując ją w teleologię wychowania, trzeba koniecznie uzupełnić ją o akceptację własnej przygodności, cielesności oraz zdolność do przebaczania sobie i innym, o ile ma być ona celem wartościowym, a nie jedynie źródłem rozczarowań i frustracji. To stwierdzenie nie przekreśla jednak możliwości poszukiwania innej odpowiedzi na sformułowane wątpliwości i pytania. Zgodnie ze stanowiskiem Jacques'a Maritaina można w tym celu zwrócić się między innymi w stronę teologii. Zastanówmy się zatem, jaką prawdę na temat osoby i osobowego rozwoju przekazuje teologia chrześcijańska.

Teoria osoby inspirowana jest niewątpliwie zapisanym na kartach Biblii objawieniem, które mówi o stworzeniu człowieka na obraz i podobieństwo Boga ( $\mathrm{Rdz} 1$, 26-27). Z ksiąg Starego i Nowego Testamentu odczytać można bardziej szczegółowy obraz tego, na czym polega to podobieństwo. Składają się na nie przede wszystkim rozumność i wolność. Dzięki nim człowiek zdolny jest do podejmowania rozumnych decyzji, może przekształcać świat, który powierzony został jego opiece, zdolny jest ponadto do dialogu z Bogiem. Według Biblii człowiek obdarzony został zatem przez Boga szczególną godnością (Bagrowicz 2008; Granat 1976).

Od pierwszych wersetów Księgi Rodzaju Biblia przekazuje również prawdę o tym, że rozumność i wolność człowieka nie ujawniają się w każdym jego czynie, $\mathrm{w}$ wielu działaniach nie dochodzą one w pełni do głosu. Opowiadanie o grzechu pierworodnym, zaliczane do tak zwanej mitologii biblijnej, świadczy o tym, że ludzi od dawna nurtowało pytanie o przyczyny nie tylko zła moralnego jako takiego, ale również kwestie dużo głębsze: dlaczego człowiek, mimo że wie, co jest dobre, a co złe, czyni zło i dlaczego nie podąża za dobrem identyfikowanym przez rozum? Na owe pytania nie sposób udzielić jednej odpowiedzi. Próbując wyjaśnić ludzkie działanie, gdy jest ono złe w wymiarze moralnym, Biblia wskazuje jako jego 
źródła między innymi: pychę, chciwość, pożądliwość cielesną, gniew. Utożsamia je zatem zarówno z nieakceptacją własnego statusu ontologicznego (pycha), jak i z nieopanowaniem różnego rodzaju poruszeń cielesnych.

Gdy odczytuje się przesłanie Starego i Nowego Testamentu, to prawdy o szczególnej godności człowieka oraz o jego słabości łączone są z wezwaniem go do osiągnięcia doskonałości. Przybiera ono na sile w Nowym Testamencie, gdzie znajdujemy między innymi słowa: „Bądźcie doskonali, jak doskonały jest Ojciec wasz niebieski” (Mt 5, 48). Jak trudne jest osiągnięcie owej doskonałości, przekonują słowa Jezusa wypowiedziane do bogatego młodzieńca: „Jeśli chcesz być doskonały, idź, sprzedaj, co posiadasz, i rozdaj ubogim” (Mt 19, 21), czy fragment z Kazania na Górze, nakazujący miłość nieprzyjaciół: „Miłujcie waszych nieprzyjaciół i módlcie się za tych, którzy was prześladują" (Mt 5, 44) (Vanhoye 1990, s. 217-220). Konfrontując z nimi własne ograniczenia, przywiązanie do rzeczy materialnych czy trudności z miłością nieprzyjaciół, można - jak młodzieniec - „odejść zasmuconym” (Mt 19, 22). Jak uniknąć owego smutku?

Nie wychwytując przy lekturze Pisma Świętego treści normatywnych, ale mądrościowe, zauważamy, że doskonałość, a więc pełnia rozwoju osobowego, nie jest przez bohaterów biblijnych osiągana. Co więcej, relacja z Bogiem nawiązywana jest przez nich nie ze względu na ich doskonałość, ale w kontekście ich słabości. Przykładowo Mojżesz był człowiekiem gwałtownym, ufającym własnej sile, odpowiadającym przemocą na przemoc. Wielu lat trzeba było, aby dojrzał do postawy pokory i skromności (Bagrowicz, Jankowski 2005), czyli aby jego emocje podporządkowane zostały rozumowi. Z kolei Dawid - stawiany za wzór króla Izraela przedstawiany jest przez Carla Marię Martiniego w następujący sposób: „Dawid, choć wierzy i kocha Boga, jest człowiekiem okrutnym, mściwym, zmysłowym” (Martini 1998, s. 41). Włoski biblista wyjaśnia również w szczegółach, w jakich sytuacjach ujawniały się te jego cechy. Przywołując doskonałość biblijnych postaci, bardzo często nie zauważa się, że ich życie upłynęło w napięciu między słabością i realizacją powołania, jakim obdarzył ich Bóg. Nie byłoby z pewnością błędem stwierdzenie, że wierność Bogu zachowali oni w pewnym sensie dzięki owym słabościom, świadomość własnych upadków i pamięć o nich sprawiała bowiem, że u Boga szukali wsparcia. Czy osiągnęli doskonałość, czy uzyskali pełnię osobowej dojrzałości, czy może w ich życiu przeplatały się dobre i złe czyny? A może dlatego nie ustawali w realizacji życiowego powołania, ponieważ - jak pisze Anselm Grün - pogodzili się z własną niedoskonałością?

Podobny schemat dojrzewania odnajdujemy w Nowym Testamencie w historii życia Piotra. Pierwszy z apostołów stał się niewątpliwie fundamentem tworzącego się Kościoła, ale nie dzięki osobowej doskonałości. Wcześniej musiał doświadczyć własnej słabości. Poszedł za Jezusem, nie zdając sobie sprawy, dokąd prowadzi ta wędrówka. Gdy wyznawał wiarę w Niego jako mesjasza $(M k$ 8, 29), wiązał z Nim nadzieję na polityczne przemiany. Na wyjaśnienia Jezusa, że Jego posłannictwo wiąże się z cierpieniem, odrzuceniem, śmiercią, zareagował w ten sposób, że zaczął 
upominać swojego Mistrza na boku (Mk 8, 32). Towarzysząc Jezusowi, nie był z pewnością gotowy na przyjęcie prawdy o Nim; widział w Chrystusie mesjasza politycznego, który ma wyzwolić naród izraelski ${ }^{1}$. Świadczy o tym wyparcie się znajomości z Jezusem po Jego pojmaniu i znamienne słowa: „Nie znam tego człowieka, o którym mówicie” (Mk 14, 71). Od wierności przyjacielowi potężniejszy okazał się wówczas lęk o siebie. Jezusowi nie chodziło jednak o to, aby Piotr stracił życie wraz z Nim, i w spojrzeniu, o którym wspomina św. Łukasz (Łk 22, 61), apostoł nie zobaczył z pewnością wyrzutu. Martini twierdzi, że było to spojrzenie pełne miłości, w którym Piotr odkrył prawdę o sobie i prawdę o Jezusie, który go kocha (Martini 1999, s. 197). Chrześcijańskie objawienie informuje zatem, że Bóg nie oczekuje od człowieka doskonałości i nie traktuje jej jako warunku nawiązania z Nim kontaktu. Prawdę tę ukazują słowa, jakie zamieścił Johnnie Moore w książce pt. Brudny Bóg...: „Mamy [...] oczywiście nasze przywary, nasze powszednie grzechy albo złe usposobienie i tracimy cierpliwość. Chcemy rzucić papierosy lub uprawianie seksu, albo przestać palić trawę czy też skończyć z miłością do pieniędzy i nas samych - ale nigdy nam się to całkiem nie udaje. Nie potrafimy sobie wyobrazić, że Jezus może być nami zainteresowany, dopóki nie oczyścimy się trochę, dopóki nie wyczyścimy naszych szafek i nie zapanujemy nad grzechami [...]. I pośród całej tej frustracji Jezus przychodzi do nas i mówi «Witajcie w Królestwie Bożym»" (Moore 2014, s. 21-22).

Czy jest zatem możliwa doskonałość osobowa człowieka? Wydaje się, że nie. Jak wskazuje Jerzy Bagrowicz, analizując myśl św. Pawła: „z jednej strony nie wszystko zostało w człowieku zepsute, z drugiej - [...] człowiek sam absolutnie nie jest w stanie «dopełnić» siebie (por. Rz 7, 18)" (Bagrowicz 2008, s. 344). Równocześnie zamieszczona w Nowym Testamencie charakterystyka apostołów, na przykład Piotra i Pawła, czy pierwszego z męczenników - św. Szczepana, przekonuje, że taki rozwój jest możliwy, że człowiek może osiągnąć integrację wszystkich swoich władz poznawczych i związanych z pożądaniem, tak aby służyły realizacji dobra wskazanego przez rozum, nawet jeżeli pociąga ona za sobą ryzyko utraty wolności, zdrowia czy życia. Szczepan w chwili śmierci wołał przecież: „Panie, nie poczytaj im tego grzechu!” (Dz 7, 60). Owa doskonałość nie jest jednak osiągana wyłącznie w wyniku osobistych wysiłków. Jest ona dziełem Boga, mocy, jaką Bóg wspiera człowieka (Granat 1976). Kończąc analizę podjętego w niniejszym artykule zagadnienia, warto zastanowić się, co stwierdzenie to oznacza w praktyce dla refleksji personalistycznej, w tym dotyczącej pedagogii osoby.

${ }^{1}$ Ewangelista Jan dopowiada nawet, że uczniem, który sięgnął po miecz w momencie pojmania Jezusa i uciął ucho jednemu ze sług arcykapłana, był właśnie Szymon Piotr (J 18, 10). 


\section{Wnioski}

Refleksja nad kondycją człowieka prowadzi do wniosku, że człowiek, opierając się jedynie na własnych wysiłkach, nie jest w stanie osiągnąć pełni osobowego rozwoju. Jeżeli pełnię tę rozumiemy jako stan wyrażający się w całkowicie rozumnym działaniu, to znaczy polegającym na pełnym podporządkowaniu poruszeń władz zmysłowych decyzjom zapadającym w dialogu rozumu i woli, to jest on dla człowieka nieosiągalny. Przeczy temu zarówno doświadczenie niekontrolowania w pełni emocji w sytuacjach nowych, zaskakujących czy wyjątkowo trudnych, jak też świadomość mniejszych i większych wad, jakie rozwijają się w człowieku od młodości i z którymi trudno mu się niekiedy uporać do końca życia. Równocześnie - jak dopowiada teologia - pełnia osobowego rozwoju możliwa jest do osiągnięcia, gdy w ludzką słabość wkracza ze swoją mocą Bóg. Przekonanie, że człowiek dzięki swoim wysiłkom może osiągnąć pełnię osobowego rozwoju, może być w tym kontekście uznane za przejaw pychy, czyli jest to swoisty grzech pierworodny.

Dla teorii pedagogii osoby oznacza to, że należy w niej albo wyraźnie wskazywać na aspekty religijne, albo tak definiować teleologię wychowania, aby w jej ramach unikać doskonałościowego opisu osoby jako celu wychowania. W praktyce oznacza to włączenie do teleologii wychowania takich celów, jak akceptacja własnej cielesności i związanej z nią przygodności czy umiejętność przebaczania sobie oraz innemu człowiekowi.

Biorąc z kolei pod uwagę, że rozwój religijny jest wspierany przez wychowanie, ale sam w sobie nie stanowi efektu zabiegów wychowawczych (w tym sensie, że relacja religijna między Bogiem i człowiekiem, której warunkiem po stronie człowieka jest jego wiara, nie jest bezpośrednio konsekwencją działania wychowawcy), w wychowaniu należałoby podjąć działania mające na celu akceptację przez wychowanka faktu, że ani on sam, ani osoby go otaczające nie są w stanie osiągnąć takiej dojrzałości osobowej, aby wyeliminowane zostały działania nie w pełni przez nie kontrolowane czy różnego rodzaju wady. Implikuje to także przygotowanie wychowanka do podejmowania prób przebaczania krzywd doświadczanych ze strony innych osób (w tym także najbliższych) oraz przebaczania sobie tych działań, w których samemu dopuściło się zła - często nieodwracalnego i przez lata niepokojącego sumienie.

\section{Bibliografia}

Arendt H. (2010). Kondycja ludzka, tłum. Łagodzka A. Warszawa: Wydawnictwo Aletheia.

Bagrowicz J., Jankowski S. (2005). „Pan, Bóg Twój, wychowuje ciebie” (Pwt 8, 5).

Studia z pedagogii biblijnej. Toruń: Wydawnictwo UMK.

Bagrowicz J. (2008). Wychowanie personalistyczne w chrześcijaństwie. W: Rusecki

M. (red.). Personalizm polski. Lublin: Wydawnictwo KUL. 
Bell M. (2008). Forgiving someone for who they are (and not just what they've done). „Philosophy and Phenomenological Research”, nr 3, s. 625-658.

Górski K. (1936). Wychowanie personalistyczne. Poznań: Naczelny Instytut Akcji Katolickiej.

Granat W. (1976). U podstaw humanizmu chrześcijańskiego. Poznań: Księgarnia św. Wojciecha.

Grün A. (2001). Przebacz samemu sobie. Pojednanie - przebaczenie, tłum. Zychowicz J. Kraków: Wydawnictwo WAM.

Horowski J. (2013). O pedagogice chrześcijańskiej. Refleksja w kontekście pogladów Jacques'a Maritaina na temat filozofii chrześcijańskiej. „Paedagogia Christiana”, nr 1/31, s. 211-228.

Horowski J. (2009). Podmiotowość w pedagogice chrześcijańskiej o inspiracji tomistycznej. „Paedagogia Christiana”, nr 2, s. 28-39.

Maritain J. (1991). Dynamika wychowania, tłum. Ziernicki A. „Znak”, nr 9, s. 28-39.

Maritain J. (1981). Humanizm integralny. Warszawa: Krąg.

Maritain J. (1993). Od filozofii człowieka do filozofii wychowania, tłum. Ziernicki A. W: Adamski F. (red.). Człowiek - wychowanie - kultura. Wybór tekstów. Kraków: Wydawnictwo WAM.

Maritain J. (1988). Podmiotowość człowieka, tłum. Fenrychowa J. W: Maritain J. Pisma filozoficzne. Kraków: Społeczny Instytut Wydawniczy Znak.

Maritain J. (2005). Trzej reformatorzy. Luter, Kartezjusz, Rousseau, tłum. Michalski K. Warszawa: Fronda - Apostolicum.

Martini C.M. (1998). Dawid. Grzesznik i człowiek wiary, tłum. Oleksy J. Kraków: Wydawnictwo WAM.

Martini C.M. (1999). Głosić Jezusa. Medytacje nad Ewangelią św. Łukasza, tłum. Wąski S., Błaszkiewicz F. Kraków: Wydawnictwo WAM.

Moore J. (2014). Brudny Bóg. Z Jezusem zmieniać świat, tłum. Pachocki K. Poznań: Święty Wojciech.

Mróz M. (2010). Tajemnica ludzkiej nieprawości. Aktualność nauki św. Tomasza $z$ Akwinu o złu moralnym i wadach moralnych. Toruń: Wydawnictwo Naukowe UMK.

Nowak M. (2005). Pedagogika personalistyczna. W: Kwieciński Z., Śliwerski B. (red.). Pedagogika. Podręcznik akademicki. T. 1. Warszawa: Wydawnictwo Naukowe PWN.

Richards N. (1988). Forgiveness. „Ethics”, nr 99, s. 77-97.

Scheler M. (1997). Resentyment a moralność, tłum. Garewicz J. Warszawa: Czytelnik. Vanhoye A. (1990). Doskonałość, tłum. Romaniuk K. W: Leon-Dufour X. (red.). Słownik teologii biblijnej. Poznań: Pallottinum.

Wojtyła K. (1986). Miłość i odpowiedzialność. Lublin: Wydawnictwo Towarzystwa Naukowego KUL.

Wojtyła K. (1994). Osoba i czyn. W: Wojtyła K. „Osoba i czyn” oraz inne studia antropologiczne. Lublin: Wydawnictwo Towarzystwa Naukowego KUL. 
Woroniecki J. (2000). Katolicka etyka wychowawcza. T. II/1. Lublin: Redakcja Wydawnictw KUL.

Woroniecki J. (1938). Wady moralne i stopnie ich nasilenia. „Szkoła Chrystusowa”, nr 11, s. 241-249.

\title{
ISSUES CONSIDERED WITH REGARDS TO THE PEDAGOGY OF THE PERSON THEORY: CORPOREALITY, CONTINGENCY, FORGIVENESS
}

\begin{abstract}
The text attempts to answer the following questions: does the theory of the person and the theory of the pedagogy of the person accord with the human condition?; do these theories support pedagogy of the person or do they rather obstruct the pedagogy as the theories encourage to embody the unattainable human persons' model? In my attempts to answer these questions, I consider the problem of forgiveness as one of the dimensions of man's personal updating dimension as well as the problem of moral defects that develop in human nature alongside the moral virtues. The analysis concludes that development of the person in full is impossible for man to attain. Accordingly, I seek the dimensions the person's pedagogy should be extended with in order to be adequate to the human condition. I identify the two issues recognised in the pedagogy of the person theory: upbringing towards own body and contingency approval and education towards forgiveness - forgiving oneself and others. My considerations are also supported with theological reflections.
\end{abstract}

Key words: person, pedagogy, body, contingency, forgiveness

Jarosław Horowski - doktor, adiunkt w Katedrze Teorii Wychowania na Wydziale Nauk Pedagogicznych Uniwersytetu Mikołaja Kopernika w Toruniu. Ważniejsze publikacje: Wychowanie moralne wedlug pedagogiki neotomistycznej (2015), Paedagogia perennis $w$ dobie postmodernizmu. Wychowawcze koncepcje o. Jacka Woronieckiego a kultura przełomu XX i XXI wieku (2007). Adres korespondencyjny: Wydział Nauk Pedagogicznych UMK, ul. Lwowska 1, 87-10o Toruń. Adres e-mail: jarohor@umk.pl. 